\title{
Influence of accumulation of heaps of steel slag on the environment: determination of heavy metals content in the soils
}

\author{
JAVIER GARCIA-GUINEA ${ }^{1}$, VIRGILIO CORRECHER ${ }^{2}$, LORENA RECIO-VAZQUEZ ${ }^{1}$, \\ ELENA CRESPO-FEO ${ }^{1}$, RAFAEL GONZALEZ-MARTIN ${ }^{1}$ and LAURA TORMO ${ }^{1}$ \\ ${ }^{1}$ Museo Nacional de Ciencias Naturales, Calle de Jose Gutierrez Abascal, 2, Madrid, 28006 Spain \\ ${ }^{2}$ CIEMAT, Av. Complutense, 22, Madrid, 28040 Spain
}

Manuscript received on June 2, 2008; accepted for publication on July 25, 2009

\begin{abstract}
The presence of high level of heavy metals involves a human healthy risk that could induce chronic diseases. This work reports on the metal contamination due to heaps of steel-slag accumulated during more than 40 years in allotments and industrial areas in the southern part of Madrid (Spain). Several slag and soil samples were collected in an area of $10 \mathrm{~km}^{2}$ and characterized by different conventional (XRD and XRF) and no so common methods (ESEM, thermoluminescence and EDS-WDS). The analysis reveal the presence of: (i) important amounts of $\mathrm{Fe}(43 \%), \mathrm{Mg}(26 \%), \mathrm{Cr}$ (1.1\%), Mn (4.6\%), S (6.5\%) in the form of Fe-rich slag phases (wüstite, magnetite...), Si and Ca-rich phases (larnite, ghelenite...), $\mathrm{Cr}$ (chromite), Mn (bustamite) and graphite, (ii) traces of some other contaminants such as $\mathrm{Cr}$ (7700 ppm), Zn (3500 ppm), Ba (3000 ppm), Pb (700 ppm) or $\mathrm{Cu}(500 \mathrm{ppm})$ on pathway soil samples that come from the steel slag, and (iii) $\mathrm{Co}$ (13 ppm), Pb (78 ppm) and V (54 ppm) in farmland soil samples. Although the existing heavy metals content is not appropriate for the current use, the extremely high metal contamination of the surrounding areas is more worrying. The properties of the soil farmlands ( $\mathrm{pH}$ circa 7, 13\% of clay, mainly illite, and $1-4 \%$ of organic matter content) show suitable conditions for the retention of cationic metals, but further studies on the movilization of these elements have to be performed to determine the possibility of severe human health risks. This sort of study can provide useful information for the politicians regarding the appropriate use of the territory to prevent possible health hazard for the population.
\end{abstract}

Key words: EDS, ESEM, metal contamination, steel slag, TL, XRD, XRF.

\section{INTRODUCTION}

The production of iron and steel yields important amounts of slag as by-products, which is one of the main sources of metal environmental pollution. Long time ago, the industrial activities were characterized by a lack of pollution control involving a potential release not only represented by hazardous chemicals (organic, organometallics or inorganic compounds), but also by metals into the environment. There is concern all over the world as the accumulation of metals increases the direct or indirect risks to human beings, since they pro-

Correspondence to: Virgilio Correcher

E-mail: v.correcher@ciemat.es duce toxic effects such as neurological, hepatic, cancer or renal upsets. It is well-known that, for instance, high levels of: (i) cobalt could act inhibiting the growth of plants (Chatterjee and Chatterjee 2000) and could harm lungs and heart (ATSDR 2004); (ii) lead could induce damage in nervous system or kidneys (ATSDR 2007); depending on the $\mathrm{pH}$, the solubility and bioaccessibility of lead from soils can change (Ren et al. 2006); (iii) vanadium could produce lung irritation, coughing, wheezing, chest pain, runny nose and a sore throat (ATSDR 1992); however, there is few information about vanadium contamination (Mochizuki et al. 1999).

Nowadays, the Spanish authorities do a strict regulation to establish controls of metal concentration on the 
soil to improve the environmental quality, and, thereby, decrease the risk on the population. Based partially on the CLEA (Contaminate Land Exposure Assessment) model employed in England and Wales (Environment Agency 2002), the local authorities in Madrid (Spain) standardized the levels of soil contaminants assuming three different scenes depending on the land use: industrial, urban and others (e.g. agricultural crops) (Comunidad de Madrid 2006). Of course, it should be necessary to take into account many other aspects, such as the form of the elements (with mobile forms or not), the type of soil (with clay minerals) and the concentration of humus (Palm 1994, Grytsyuk et al. 2006). One of the main challenges required from the local authorities or policy makers concerning the metal contamination is to define new methodologies that are faster, simpler, more reliable and cheaper, which look for different and sensitive analytical techniques to discriminate, among others, (i) geogenic and anthropogenic origin of metal concentration, (ii) biological interactions including oxidation-reduction processes, (iii) phase complexation, (iv) precipitation, (v) dissolution, etc. In addition to the conventional methods commonly employed for sample characterization (X-ray diffraction, XRD, scanning electron microscope, SEM, Inductively Coupled Plasma Mass Spectrometry, ICPMS, or X-ray fluorescence, XRF), there are some others techniques that could contribute especially to singleparticle characterization, namely: environmental scanning electron microscope (ESEM), thermoluminescence (TL) or energy-dispersion, and wavelength-dispersive spectrometry (EDS-WDS), depending on the nature of different soil constituents. All of them show pros and cons, but all together offer an excellent sample characterization since the deficiency of one technique can be covered by some of the others (Gunst et al. 2000).

The area here studied (Getafe), which is located in the southern part of Madrid (Spain) in the Manzanares River basin, is one of the most industrialized areas with more than 150000 inhabitants. One can easily appreciate how the many pathways, in this flat area, are paved by tons of slag heaps coming from the Aristrain's iron and steel factory covering a surface of several ha. In the steel plants of Madrid, crude steel is produced from iron ore in two stages. In the first one, coal is used to remove oxygen from the ore and to melt it, a process that produces large amounts of wüstite $(\mathrm{FeO})$, which relieves the phosphorous element. In the second step, oxygen and $\mathrm{CaCO}_{3}$ are added to reduce the carbon content of the melt. This produces calcium silicates such as gehlenite, larnite and bredigite (Luxan et al. 2000), which help to remove the sulphur. During both stages, huge amounts of carbon dioxide are produced; as an example, the Japanese iron and steel industry accounts for approximately $15 \%$ of all Japan's greenhouse gas emissions (Gielen and Moriguchi 2002). The aim of the present work is to determine the effect of the presence of the aforementioned heaps of steel slag in a part of the district of Getafe environment. For such purpose, several slag and soil samples, selected from different areas, have been analysed by conventional mineralogical and geochemical methodology that provide information on the spread of contamination in the affected area. Thus, XRD, ESEM, XRF, TL and EDS-WDS have been performed to the sample characterization.

\section{EXPERIMENTAL}

Fifteen representative samples, among almost 200 collected, were selected in an area of about $10 \mathrm{~km}^{2}$ including allotments and industrial suburbs in Villaverde-GetafeParla, in the southern part of Madrid (Spain) surrounding the Aristrain's iron and steel factory. All sampling locations were on ground with unrestricted access. The slag phases were characterized by X-ray powder diffraction using a Phillips PW1710/00 powder diffractometer with a $\mathrm{CuK}_{\alpha}$ radiation source, equipped with a graphite monochromator. Patterns were obtained by step scanning from $2^{\circ}$ to $64^{\circ}$ ( $2 \theta$ in steps of $0.020^{\circ} ; 4$ s per step) and compared with the XRD card files of the Joint Committee on Powder Diffraction Standards. Mineral identification was performed using X-powder software developed by Martin-Ramos (2004). Slag samples were also analyzed using a FEI QUANTA 200 ESEM operating under low vacuum conditions and equipped with both secondary electron and backscattering detectors. The microscope was equipped with two X-ray detectors (Oxford Analytical-Inca Instruments) that could be used simultaneously or in alternating mode. The average and single-spot chemical analysis of samples was performed using EDS-WDS (30kV; work distance $10 \mathrm{~mm}$ ) in large samples, i.e., up to $5 \times 5 \mathrm{~cm}^{2}$. The WDS analyses were performed on well-polished samples covered 
with sputtered graphite, under high vacuum conditions $\left(10^{-4}\right.$ torr). WDS can detect elements at concentrations one order of magnitude lower than EDS can using the following standards: (C) Calcite, $(\mathrm{Fe})$ Iron, $(\mathrm{Ba}) \mathrm{BaF}_{2}$, (Mn) Manganese, (Cr) Chromium, (Cl) NaCl, (Na) Albite, (Si) Orthoclase, (Al) Orthoclase, (K) KBr, (Ti) Titanium, (Cu) Copper, (P) GaP, (Sn) Sn, (S) Pyrite and $(\mathrm{Mg})$ periclase. TL measurements were achieved using an automated Risø TL system model TL DA-12 (Bøtter-Jensen and Duller 1992); this TL-reader is provided with an EMI 9635 QA photomultiplier, and the emission was observed through a blue filter (FIB002 of the Melles-Griot Company), in which the wavelength is peaked at $320-480 \mathrm{~nm}$; FWHM is $80 \pm 16 \mathrm{~nm}$ and peak transmittance (minimum) is $60 \%$. It is also provided with a ${ }^{90} \mathrm{Sr} /{ }^{90} \mathrm{Y}$ source with a dose rate of $0.021 \mathrm{~Gy} \mathrm{~s}^{-1}$ calibrated against a ${ }^{60} \mathrm{Co}$ photon source in a secondary standards laboratory (Correcher and Delgado 1998). All TL measurements were made using a linear heating rate of $5 \mathrm{~K} / \mathrm{s}$ from room temperature up to $773 \mathrm{~K}$ under $\mathrm{N}_{2}$ atmosphere. Four aliquots of $5.0 \pm 0.1 \mathrm{mg}$, each of the 15 steel slag samples were used for each measurement. The samples were carefully powdered with an agate pestle and mortar to avoid triboluminescence (Garcia-Guinea and Correcher 2000). Analysis of soil sample was carried out by X-Ray Fluorescence using a Philips PW1410 spectrometer with $\mathrm{Sc}-\mathrm{Mo}$ tube $(\mathrm{Si}, \mathrm{Al}, \mathrm{Ti}, \mathrm{Fe}, \mathrm{Mg}, \mathrm{Mn}$, $\mathrm{Ca}, \mathrm{Na}$ and $\mathrm{K}$ elements).

\section{RESULTS AND DISCUSSION}

\section{Geological Frame and Sampling Area}

The studied area is situated in the Manzanares River basin where Terciary age formations are incised by younger Quaternary age materials as river deposits. The lithologies of Tertiary materials are mainly composed by clay-rich levels with two different associations, gypsum and sandstone (Fig. 1a). The first formation is a thick level of brownish clays with intercalated beds of gypsum and gypsum-rich marls ranging from 0.5 to $1 \mathrm{~m}$ thickness and growing downwards. The second type of materials is a greenish clay level with micaceous sands and small amounts of dolomite and chert. The claystone compositions are mainly smectite-illite and illite, with less than $15 \%$ in kaolinite for both formations. Con- cerning the Quaternary river-banks and valley-filled materials, they are composed by many different gravel types with minor quantities of sands and slime. The valley-filled sediment levels covering the top of the riverbanks, with 1 to $5 \mathrm{~m}$ in depth, are composed by gross to medium sized sands (Fig. 1a). The sand is mainly formed by quartz with very small parts of granitoid, chert, sepiolite and limestone. A quarry is close to the studied area for extracting quartz-rich sands. The sampled area $\left(10 \mathrm{~km}^{2}\right)$ holds important amounts of steel and iron slag samples, which are usually employed to pave pathways in local allotments and is consequently exposed to weathering by rainfall, wind and different types of vehicles. Nowadays, this area combines industrial and agricultural activities and the population is progressively increasing. Figure $1 \mathrm{~b}$ depicts a sketch in which the irrigated and dry-farmed lands are quite close to the local path mainly formed by clays, gypsum and mudstone, and covered by a $60 \mathrm{~cm}$-layer of slag dumps.

\section{STEEL-SLAGs CHARACTERIZATION}

All collected samples, located at $30 \mathrm{~cm}$ depth from the surface, exhibit a high level of porosity regardless the size of the piece (Fig. 2). This property is especially interesting for local farmers who use this material in the farmlands since it can host amounts of water that are very useful during drought periods. Such behavior is also observed in some areas of Canary Islands where local farmers employ fragments of lava (also high porosity materials) for similar purposes. At a glance, one can guess a very different composition of the specimens because of (i) the color (from deep black to greyish), (ii) the texture (glassy with several drop-shaped inclusions), (iii) the size of pore and (iv) the density that differs considerably from sample to sample. The mineralogical composition was determined by XRD (powder method), and most of the samples are a mixture of several phases. The list of the identified phases with the corresponding stequiometric composition and the ICDD (International Centre for Diffraction Data) XRD reference cards are shown in Table I. This analysis shows, on one hand, plenty of uncommon mineral phases such as $\mathrm{Si}$ and Ca-rich phases (larnite, ghelenite, pseudowollastonite), and graphite indicating a synthetic origin (from the factory) and, on the other hand, the presence of high 

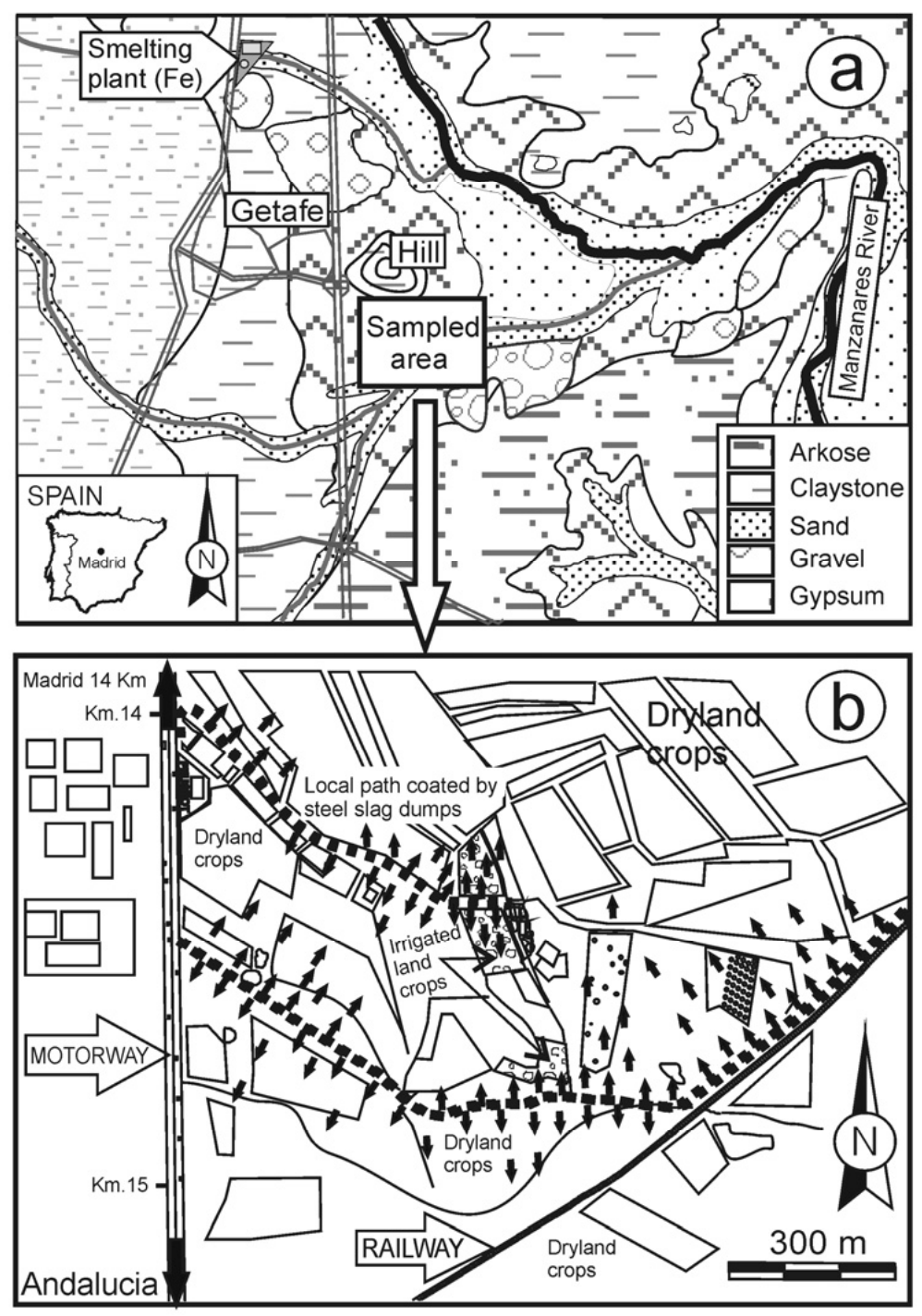

Fig. 1 - (a) Geological sketch of the studied and sampled area. (b) Location map of the area affected by the presence of steel-slag dumps.

concentration of metal contaminants such as $\mathrm{Fe}(43 \%)$, $\mathrm{Mg}$ (26\%), Cr (1.1\%), Mn (till 4.6\%), in the form of Fe-rich slag phases (wüstite, magnetite, goethite...), $\mathrm{Cr}$ (chromite), and Mn (bustamite), with an important content of S $(6.5 \%)$.

These steel slag materials could create confusion among beginners that have been catalogued as meteorites or 'pseudometeorites' due to their external aspect. Nevertheless, possible doubts about this fact can be clarified by the TL technique that arises as a good possibility to discriminate meteorites from steel slag. TL is a method based on the emission of light from a solid sample (insu- lator or semiconductor) when it is heated after being irradiated by some kind of radiation such as X-rays, gamma rays, beam of electrons, cosmic rays, etc. (McKeever 1985). During the heating, the TL signal is detected by a photomultiplier tube and recorded as a function of the temperature or wavelength. The resulting curve is called a TL curve or glow curve; the luminescent intensity and the shape of this glow curve are functions of radiation dose and heating rate. The presence of a huge amount of samples, close to the iron smelting factory, and the mineralogical composition, allow us to speculate about the origin of the sample; however, some TL tests have been 


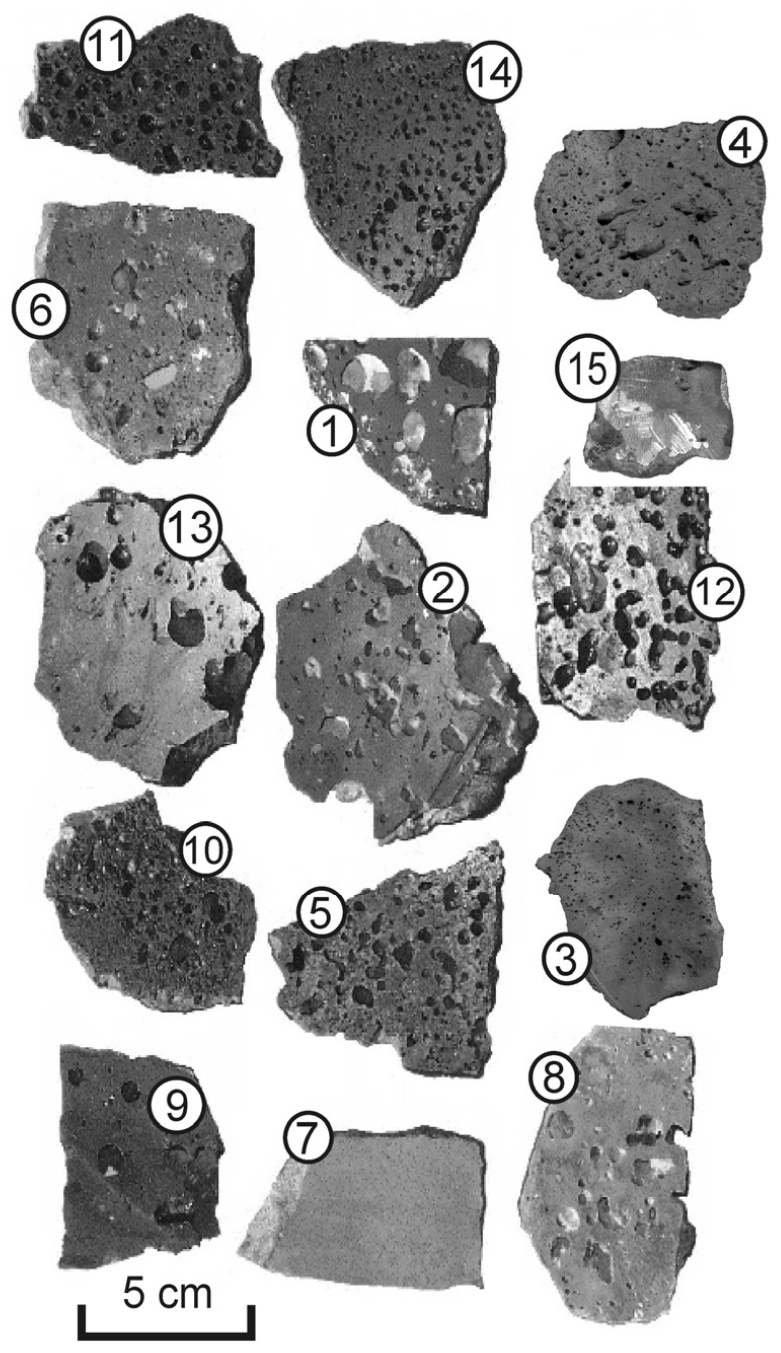

Fig. 2 - Fifteen of the more representative steel slags samples, selected among 200 specimens, from different places of VillaverdeGetafe-Parla in an area of $10 \mathrm{~km}^{2}$ in the southern part of Madrid.

carried out to distinguish geogenic from anthropogenic origin of the samples. The meteorites that come from the main asteroid belts placed between Jupiter and Mars have usually been exposed to high levels of radiation (cosmic rays) and the presence inside of such meteorites of cosmogenic radioisotopes for a long time. This fact concerns the samples that arrive at the Earth's surface possessing a very intense TL signal regardless of their composition.

In Figure 3, 14 collected samples and one catalogued 'pseudometeorite' TL spectra are shown. This last sample is identified as the fragment that hit a car in 1994 at $17 \mathrm{~km}$ from Madrid in the Andalusia Motorway (between Getafe and Villaverde villages), and considered by Dr. Martínez-Frías to be a possible meteorite or even more, a pseudo-meteorite (Martínez-Frías 1998, Martínez-Frías et al. 1999, 2004). All of the collected samples tested (four replicates each) exhibit a very low TL intensity, never higher than 200a.u. Although the sample number 1 is four times brighter than the rest (up to 800 a.u.), the TL emission of this sample can be considered almost negligible when compared to the natural TL of other terrestrial and particularly extraterrestrial samples (Correcher et al. 2007). This bigger intensity is probably due to the several analyses that have been made in different North American laboratories concerning not only short irradiations during the studies of the samples over the last ten years, but also the assorted Xrays at airport controls during the journeys among the laboratories. The conclusion after the TL study is that the 15 samples exhibit a very low TL emission because the last heating (usually known as 'zeroing') of the samples were made only a short time ago (less than 50 years) and never compared with geological times.

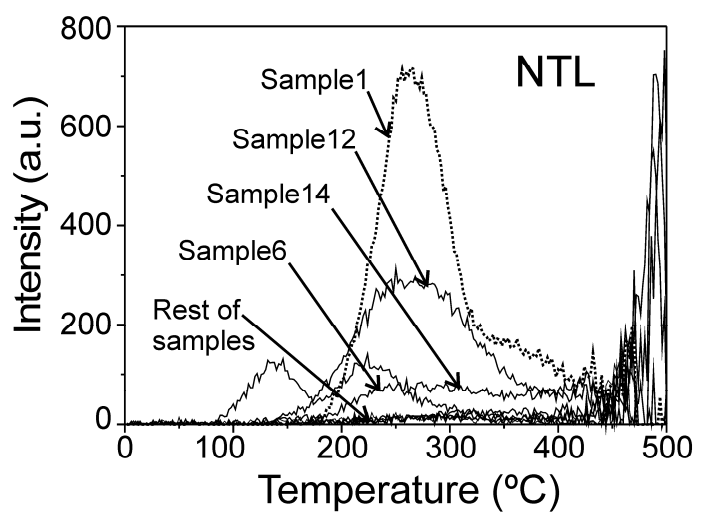

Fig. 3-Thermoluminescence glow curves of slag materials; note the low emission signals in all cases.

Some of selected ESEM images obtained from two of the slags (number 2 and 10) are respectively shown in Figures $4 \mathrm{a}$ and $\mathrm{b}$. As illustrated in Figure 4a, the core corresponds to a grain of leftover $\mathrm{MgCO}_{3}$, i.e., a magnesite refractory phase surrounded by an external rim composed of a mixture of $\mathrm{MgCO}_{3}$ and $\mathrm{FeO}$. The matrix contains little amounts of calcium-iron silicates, calcium-iron carbonates and iron carbonates undetected by XRD. It is interesting to note the presence of sparkling inclusions of $\mathrm{BaCO}_{3}-\mathrm{BaSO}_{4}$. Both types 
TABLE I

Quantitative analyses of slag phases (in percentage) by X-ray diffraction (powder method) including (i) the list of the detected phases in the analyzed steel slag, (ii) the ICDD (International Centre for Diffraction Data) card file for XRD and (iii) the stequiometric formula.

\begin{tabular}{|c|c|c|c|c|c|c|c|c|c|c|c|c|c|c|c|c|c|}
\hline \multirow{2}{*}{ Phases } & & \multirow{2}{*}{$\mathrm{ICDD}^{*}$} & \multicolumn{15}{|c|}{ Sample number } \\
\hline & & & 1 & 2 & 3 & 4 & 5 & 6 & 7 & 8 & 9 & 10 & 11 & 12 & 13 & 14 & 15 \\
\hline Wüstite & $\mathrm{FeO}$ & 6-615 & 47 & 51 & 35 & & 50 & & & 85 & & 60 & 50 & & 20 & & \\
\hline Larnite & $\mathrm{Ca}_{2} \mathrm{SiO}_{4}$ & $29-371$ & 18 & 4 & & & & & & & 15 & & 30 & & & & \\
\hline Gehlenite & $\mathrm{Ca}_{2} \mathrm{Al}_{2} \mathrm{SiO}_{7}$ & $35-755$ & 25 & & 40 & 58 & 25 & & & & 5 & & & 75 & & & \\
\hline Chromite & $\mathrm{FeO} .(\mathrm{Cr}, \mathrm{Al})_{2} \mathrm{O}_{3}$ & $34-140$ & 10 & 8 & & & & & & & & 25 & & & 15 & & \\
\hline Magnetite & $\mathrm{FeO} . \mathrm{Fe}_{2} \mathrm{O}_{3}$ & $19-629$ & & & 25 & & & & & & & 5 & & & & & \\
\hline Kirschteinite & $\mathrm{CaFeSiO}_{4}$ & $34-98$ & & 22 & & 39 & 20 & & & & & & & 25 & 30 & & \\
\hline Monticellite & $\mathrm{CaMgSiO}_{4}$ & $35-590$ & & & & & & & & & & & & & 35 & & \\
\hline Akaganeite & $\beta$-FeOOH & $34-1266$ & & & & & 5 & & & & & & & & & & \\
\hline Bredigite & $\mathrm{Ca}_{7} \mathrm{Mg}\left(\mathrm{SiO}_{4}\right)_{4}$ & $36-399$ & & & & & & & 95 & & & & & & & & \\
\hline Bustamite & $(\mathrm{Mn}, \mathrm{Ca})_{3} \mathrm{Si}_{3} \mathrm{O}_{9}$ & 26-1066 & & & & & & 100 & & & & & & & & & \\
\hline Graphite & $\mathrm{C}$ & $25-284$ & & & & & & & 5 & & & & & & & & \\
\hline Mayenite & $\mathrm{Ca}_{12} \mathrm{Al}_{14} \mathrm{O}_{33}$ & $9-413$ & & 12 & & & & & & 15 & 80 & 10 & 15 & & & & \\
\hline Quartz & $\mathrm{SiO}_{2}$ & $33-1161$ & & & & & & & & & & & & & & 3 & \\
\hline Calcite & $\mathrm{CaCO}_{3}$ & $5-586$ & & & & & & & & & & & & & & 2 & 10 \\
\hline Sillimanite & $\mathrm{Al}_{2} \mathrm{O}_{3} \cdot \mathrm{SiO}_{2}$ & $38-471$ & & & & & & & & & & & & & & & 90 \\
\hline Magnesite & $\mathrm{MgCO}_{3}$ & $80-870$ & & 3 & & & & & & & & & 5 & & & & \\
\hline Goethite & $\alpha-\mathrm{FeOOH}$ & $29-713$ & & & & 3 & & & & & & & & & & & \\
\hline Pseudo-wollastonite & $\mathrm{CaSiO}_{3}$ & $31-300$ & & & & & & & & & & & & & & 95 & \\
\hline
\end{tabular}

of neo-formed inclusions of $\mathrm{MgCO}_{3}$ and $\mathrm{BaCO}_{3}$ can be explained by the use of dirty natural limes $\left(\mathrm{CaCO}_{3}\right.$ with $\mathrm{CaMg}\left(\mathrm{CO}_{3}\right)_{2}$ or dolomite with barite veins $\left(\mathrm{BaSO}_{4}\right)$, typical of Palaeozoic limestones). In addition, the presence of $1 \%$ copper and $1 \%$ chromium could be better explained as coming from electrical wires or scrap chromium steel. Some neo-formed hematite $\left(\mathrm{Fe}_{2} \mathrm{O}_{3}\right)$ spheres with hexagonal crystal shapes are recognizable within some slag samples, as micrometer scale grains (Fig. 4b that corresponds to the slag 10). The compositions of the number 2 slag corresponding to white core, colourless rim, external rim, brown matrix, white and dark areas in the matrix and sparkling inclusions are shown in Table II. These analyses indicate that the maximum relative content of iron is mainly located in the matrix and in the external rim of the slag, which could help this metal to diffuse in a more suitable way from the slag to the environment. Average and singlespot analyses were plotted successively from the white core to the encircling matrix. In general, dark areas in the samples can be linked in the presence of high relative concentrations of $\mathrm{Fe}$. Some amounts of toxic metals (i.e., barium, copper and tin) have been also detected by EDS-WDS; however, the concentration levels seem not to be very significant to speculate with sub- sequent higher levels of contamination in soil samples. The oxygen:iron ratio suggests that the above crystals are composed of hematite $\left(\mathrm{Fe}_{2} \mathrm{O}_{3}\right)$ with accessory mayenite $\left(\mathrm{Ca}_{12} \mathrm{Al}_{14} \mathrm{O}_{33}\right)$. The list of stable phases at room temperature (Table I) shows that the sample had passed through the two classic stages of steel production (Parais 1978). In the first step, large amounts of carbon are added; in this piece of slag, some amounts of graphite and wüstite $(\mathrm{FeO})$ could be found. The latter is unstable under normal environmental conditions and appears as a white, oxidised crust. This carbon is usually added to raw material to remove oxygen from ores and to melt them. As observed in Figure 5a, one can appreciate the presence of large amounts of wüstite in the slag number 2 that were produced during the manufacturing process to induce a strong iron dephosphorylation usually from $0.2 \%$ up to $0.01 \%$. Similarly, Figure 5 b explains the great abundance of calcium-iron silicates in this slag, since large amounts of limestone are added to bring about greater desulphurisation during the second manufacturing step. In this second step, oxygen was used to decrease the carbon content in the melt by the addition of dirty lime, which was revealed by the presence of abundant magnesium-calcium silicates in the iron slag. The existence of aluminium in the slag can be explained 

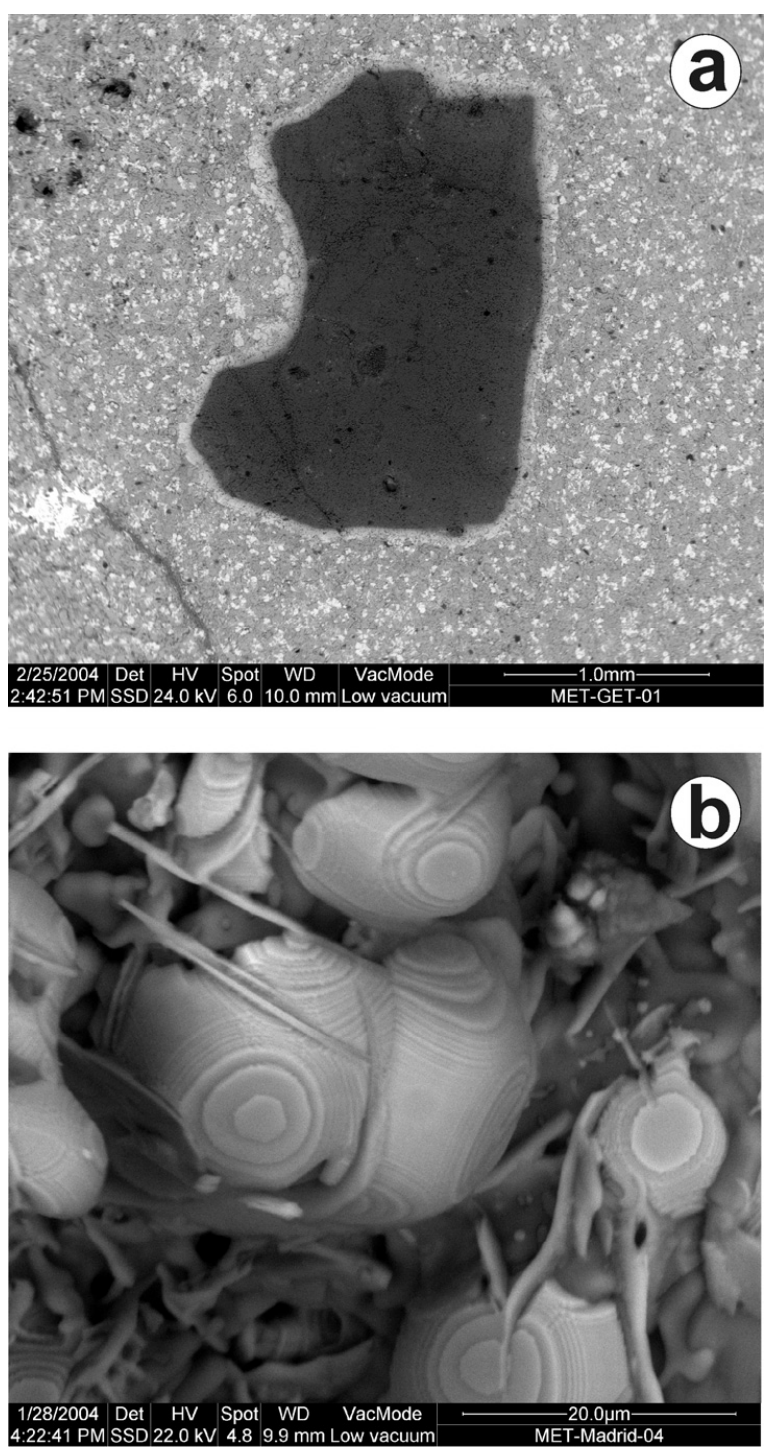

Fig. 4 - Selected images from the ESEM analyses: (a) Magnesite $\left(\mathrm{MgCO}_{3}\right)$ grain and (b) Hematite $\left(\mathrm{Fe}_{2} \mathrm{O}_{3}\right)$ spherical crystals; note the hexagonal shapes along the $c$ axis.

by the use of clay or feldspar raw materials in the second manufacturing stage; these materials generate unstable mayenite oxide $\left(\mathrm{Ca}_{12} \mathrm{Al}_{14} \mathrm{O}_{33}\right)$.

As the composition of the slags involves a high content of heavy metals, the recycling of steel slags is of great interest for both the conservation of natural mineral resources and the decrease of metal contamination. Currently, modern or modernized steelmaking factories, such as the Aristrain plant at Villaverde, do the recycle of slag, which reduces the manufacturing costs while being more environmental friendly. The final slag prod-
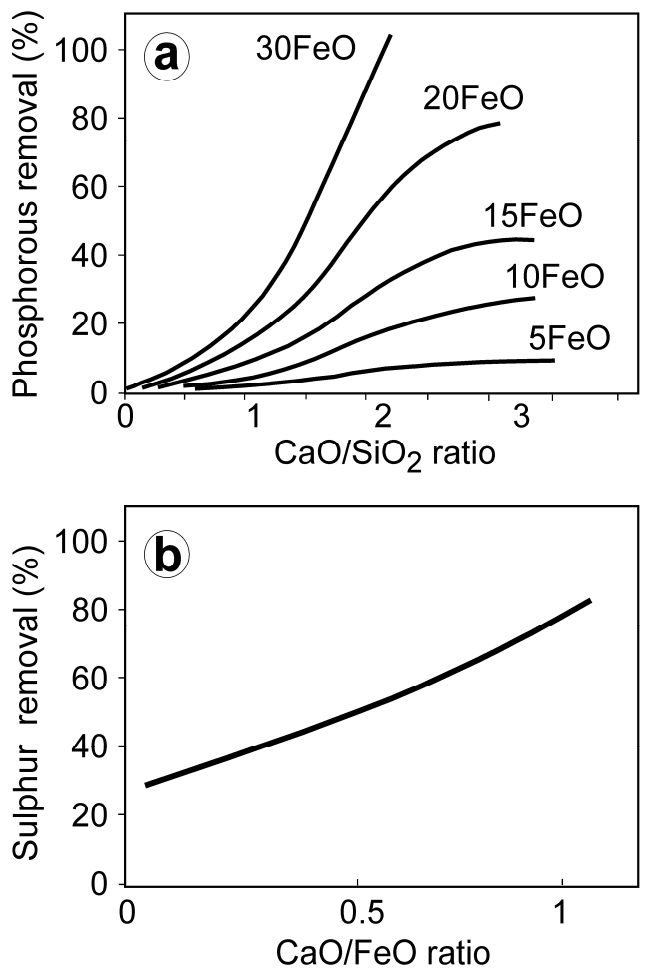

Fig. 5 - (a) Evolution of the Phosphor release depending on the $\mathrm{CaO} / \mathrm{SiO}_{2}$ ratio. It explains the great abundance of wüstite in the Getafe slag heaps: large amounts of it were produced in the manufacturing process to induce greater dephosphorylation of the iron. (b) Sulphur removal versus $\mathrm{CaO} / \mathrm{FeO}$ ratio. It makes clear the abundance of calcium-iron silicates: large amounts of them were produced to induce greater desulphurisation during the second manufacturing step.

ucts are discarded at controlled recycling centers to prevent the transfer of heavy metals to the environment.

\section{Chemical Analysis of SoIls}

The concentration of heavy metals was measured in eight different points of pathways close to the irrigated farmlands (Table III) and five sites inside the farmlands (Table IV). The first ones were collected about $0.5 \mathrm{~m}$ depth from the surface, and the soil farmland samples were taken at about $0.3 \mathrm{~m}$ depth from the surface and $10 \mathrm{~m}$ away from the main pathways.

As observed, there is a high homogeneity in the distribution of the metals in the soil samples, probably due to the presence of the slags in the studied area for more than 40 years. The results display that all the samples show different concentrations of $\mathrm{Fe}$ (up to $27.1 \%$ ), $\mathrm{Al}$ 
TABLE II

Chemical analyses performed in the ESEM by EDS on the slag sample number 2 (shown in Fig. 4).

\begin{tabular}{c|c|c|c|c|c|c|c}
\hline & $\begin{array}{c}\text { white } \\
\text { core }\end{array}$ & $\begin{array}{c}\text { colorless } \\
\text { rim }\end{array}$ & $\begin{array}{c}\text { external } \\
\text { rim }\end{array}$ & $\begin{array}{c}\text { brown } \\
\text { matrix }\end{array}$ & $\begin{array}{c}\text { white } \\
\text { areas } \\
\text { matrix }\end{array}$ & $\begin{array}{c}\text { dark } \\
\text { areas } \\
\text { in matrix }\end{array}$ & $\begin{array}{c}\text { sparkling } \\
\text { inclusion } \\
\text { in matrix }\end{array}$ \\
\hline $\mathrm{C}$ & 13.90 & 14.61 & 8.72 & 2.24 & 6.64 & 8.77 & 7.84 \\
\hline $\mathrm{Na}$ & 0.00 & 0.00 & 0.00 & 0.55 & 0.00 & 0.00 & 0.00 \\
\hline $\mathrm{Mg}$ & 26.44 & 19.95 & 7.25 & 0.39 & 2.32 & 0.50 & 0.28 \\
\hline $\mathrm{Al}$ & 0.40 & 0.73 & 1.16 & 3.07 & 2.12 & 1.01 & 1.75 \\
\hline $\mathrm{Si}$ & 0.67 & 1.72 & 1.86 & 15.93 & 2.89 & 1.42 & 3.28 \\
\hline $\mathrm{S}$ & 0.00 & 0.14 & 0.00 & 0.00 & 0.00 & 0.42 & 6.54 \\
\hline $\mathrm{P}$ & 0.00 & 0.00 & 0.00 & 0.69 & 0.00 & 0.00 & 0.00 \\
\hline $\mathrm{Cl}$ & 0.20 & 0.23 & 0.16 & 0.29 & 0.00 & 0.20 & 0.00 \\
\hline $\mathrm{K}$ & 0.13 & 0.20 & 0.10 & 1.60 & 0.00 & 0.09 & 0.00 \\
\hline $\mathrm{Ca}$ & 0.96 & 2.01 & 2.62 & 22.42 & 4.41 & 2.04 & 5.45 \\
\hline $\mathrm{Ti}$ & 0.00 & 0.00 & 0.00 & 0.41 & 0.00 & 0.00 & 0.00 \\
\hline $\mathrm{Cr}$ & 0.00 & 0.00 & 1.11 & 0.19 & 0.98 & 0.12 & 0.00 \\
\hline $\mathrm{Mn}$ & 0.00 & 0.33 & 3.69 & 0.99 & 4.58 & 0.81 & 0.64 \\
\hline $\mathrm{Fe}$ & 1.05 & 3.50 & 30.72 & 7.65 & 37.41 & 43.33 & 6.14 \\
\hline $\mathrm{Ba}$ & 0.00 & 0.00 & 0.00 & 0.00 & 0.00 & 0.00 & 33.65 \\
\hline $\mathrm{Cu}$ & 0.00 & 0.00 & 0.00 & 0.00 & 0.00 & 1.23 & 0.00 \\
\hline $\mathrm{Sn}$ & 0.00 & 0.00 & 0.00 & 2.59 & 0.00 & 0.00 & 0.00 \\
\hline $\mathrm{O}$ & 56.25 & 56.59 & 42.61 & 41.00 & 38.66 & 40.06 & 34.41 \\
\hline & & & & & & &
\end{tabular}

TABLE III

Chemical analysis performed by XRF of eight different soil samples of pathways close to the irrigated land crops. Where L.I. means Lost due to the Ignition.

\begin{tabular}{c|c|c|c|c|c|c|c|c}
\hline Element (\%) & GE-1 & GE-2 & GE-3 & GE-4 & GE-5 & GE-6 & GE-7 & GE-8 \\
\hline $\mathrm{SiO}_{2}$ & 31.64 & 34.1 & 30.64 & 37.37 & 28.91 & 31.67 & 30.14 & 31.07 \\
\hline $\mathrm{Al}_{2} \mathrm{O}_{3}$ & 7.05 & 6.94 & 6.77 & 6.86 & 6.32 & 6.55 & 6.41 & 6.72 \\
\hline $\mathrm{Fe}_{2} \mathrm{O}_{3}$ (total) & 21.8 & 20.76 & 18.64 & 17.52 & 27.14 & 21.04 & 19.59 & 20.89 \\
\hline $\mathrm{MnO}$ & 1.87 & 1.05 & 1.26 & 0.84 & 1.26 & 1.18 & 1.03 & 0.86 \\
\hline $\mathrm{MgO}$ & 4.07 & 4.04 & 4.99 & 4.3 & 5.39 & 4.63 & 5.44 & 4.97 \\
\hline $\mathrm{CaO}$ & 17.27 & 15.11 & 18.88 & 16 & 17.87 & 16.81 & 17.68 & 17.65 \\
\hline $\mathrm{Na}_{2} \mathrm{O}$ & 0.86 & 0.58 & 0.54 & 0.66 & 0.55 & 0.6 & 0.58 & 0.68 \\
\hline $\mathrm{K}_{2} \mathrm{O}$ & 1.66 & 1.95 & 1.57 & 2 & 1.45 & 1.83 & 1.69 & 1.92 \\
\hline $\mathrm{TiO}_{2}$ & 0.38 & 0.31 & 0.31 & 0.31 & 0.3 & 0.31 & 0.29 & 0.28 \\
\hline $\mathrm{P}_{2} \mathrm{O}_{5}$ & 0.31 & 0.3 & 0.32 & 0.33 & 0.25 & 0.31 & 0.27 & 0.3 \\
\hline L.I. & 13.1 & 14.86 & 16.07 & 13.81 & 10.55 & 15.06 & 16.87 & 14.66 \\
\hline Total & 100.01 & 100 & 99.99 & 100 & 99.99 & 99.99 & 99.99 & 100 \\
\hline
\end{tabular}

(up to $7.1 \%$ ), $\mathrm{Mn}$ (up to $1.9 \%$ ) and $\mathrm{Cr}$ (up to $7726 \mathrm{ppm}$ ), $\mathrm{Zn}$ (up to $3531 \mathrm{ppm}$ ), $\mathrm{Ba}$ (up to $3143 \mathrm{ppm}$ ), $\mathrm{Pb}$ (up to $759 \mathrm{ppm}), \mathrm{Cu}$ (ca. $500 \mathrm{ppm}$ ), etc, in pathway samples. The measurements performed on the soil samples of the farmlands were carried out in 5 different zones (Table IV). In general, the results exhibit heavy metals values lower than the recommended values. However, in some cases, the heavy metals concentration exceeds slightly the allowed limits described in the local regulation (Co- munidad de Madrid 2006). Thus, one can appreciate how the $\mathrm{Co}, \mathrm{Pb}$ and $\mathrm{V}$ concentration in soil samples of farmlands with tomato crops goes over the limit of the Spanish recommendation value for human intake. These three metals, together with $\mathrm{Cu}, \mathrm{Ni}, \mathrm{Zn}, \mathrm{Cr}$ and $\mathrm{Ba}$, have to be controlled by the European Union (EU) (Covelo et al. 2007). In the case of soil samples from the boundaries among the farmlands, the concentration of all previous heavy metals (except $\mathrm{Ni}$ and $\mathrm{Ba}$ ) exceeds the reference 
TABLE IV

Comparison between the reference levels of heavy metals for the protection of human health in Madrid (Comunidad de Madrid 2006) and the concentration of heavy metals in different soil samples.

\begin{tabular}{|c|c|c|c|c|c|c|c|c|c|c|c|c|c|c|c|c|}
\hline \multicolumn{9}{|c|}{$\begin{array}{l}\text { Soil samples of pathways close to the irrigated farmlands } \\
\text { Traces }(\mathrm{mg} / \mathrm{kg})\end{array}$} & \multicolumn{3}{|c|}{$\begin{array}{l}\text { Reference level } \\
\qquad(\mathrm{mg} / \mathrm{kg})\end{array}$} & \multicolumn{5}{|c|}{$\begin{array}{l}\text { Soil samples from farmlands } \\
\text { Traces }(\mathrm{mg} / \mathrm{kg})\end{array}$} \\
\hline Metal & GE-1 & GE-2 & GE-3 & GE-4 & GE-5 & GE-6 & GE-7 & GE-8 & $\begin{array}{c}\text { Industrial } \\
\text { Use }\end{array}$ & $\begin{array}{c}\text { Urban } \\
\text { Use }\end{array}$ & $\begin{array}{l}\text { Other } \\
\text { Uses }\end{array}$ & $\begin{array}{c}\text { Field } \\
1\end{array}$ & $\begin{array}{c}\text { Field } \\
2\end{array}$ & $\begin{array}{c}\text { Field } \\
3 \\
\end{array}$ & $\begin{array}{c}\text { Field } \\
4 \\
\end{array}$ & $\begin{array}{c}\text { Field } \\
5\end{array}$ \\
\hline $\mathrm{Cu}$ & 438 & 446 & 370 & 382 & 453 & 497 & 422 & 447 & 8000 & 800 & 80 & 20 & 17 & 7 & 52 & 23 \\
\hline $\mathrm{Ni}$ & 154 & 160 & 124 & 136 & 200 & 191 & 160 & 187 & 15600 & 1560 & 405 & 14 & 17 & 12 & 18 & 13 \\
\hline Co & 46 & 50 & 40 & 42 & 68 & 51 & 44 & 50 & 1500 & 150 & 15 & 11 & 13 & 9 & 11 & 10 \\
\hline $\mathrm{Zn}$ & 3531 & 2507 & 2650 & 2950 & 2847 & 3144 & 3280 & 3514 & 100000 & 11700 & 1170 & 95 & 100 & 49 & 161 & 90 \\
\hline $\mathrm{Pb}$ & 525 & 512 & 502 & 593 & 515 & 583 & 531 & 759 & 2700 & 270 & 75 & 59 & 32 & 27 & 78 & 52 \\
\hline $\mathrm{Cr}$ & 7726 & 4500 & 4648 & 3123 & 5371 & 4169 & 3964 & 3410 & 2300 & 230 & 90 & 37 & 50 & 32 & 51 & 33 \\
\hline $\mathrm{V}$ & 184 & 107 & 122 & 89 & 123 & 108 & 109 & 88 & 3700 & 370 & 37 & 38 & 54 & 29 & 51 & 32 \\
\hline $\mathrm{Ba}$ & 3143 & 1615 & 2010 & 1257 & 1819 & 1732 & 1724 & 1543 & 100000 & 15200 & 4200 & 549 & 480 & 448 & 597 & 544 \\
\hline
\end{tabular}

value for the protection of human health either for any land use ( $\mathrm{Cu}, \mathrm{Co}, \mathrm{Zn}, \mathrm{Pb}, \mathrm{Cr}$ y V), such as urban use ( $\mathrm{Cr}$ $\mathrm{y} \mathrm{Pb})$, or even industrial use $(\mathrm{Cr})$. Some of these values (especially for $\mathrm{Cr}$ ) are in somehow worrying, and further studies should be done to determine in which way metals appear in the soil and to what extent their concentration involves a risk to human health. With regard to the samples of the farmlands, the only heavy metals that are at a concentration higher than the one allowed by the actual law for agricultural land use (other uses) are $\mathrm{Pb}$ and $\mathrm{V}$ (samples 2 and 4). These comparatives data are shown in Table IV. Such metals have been included in the Priority Pollutants List, which was created by the U.S. Environmental Protection Agency in 1993. Apart from the measurements of trace elements concentrations of these soils, there are some other properties to take into account: $\mathrm{pH}$, textural class, and percentage organic matter. The behavior of different metals and the reactivity of the variable electric charge in soils depend on the $\mathrm{pH}$ (Bradl 2004). The textural class of the soil is a basic property because various processes of adsorption of metals are largely conditioned by phyllosilicate and metallic oxyhydroxides, which appear in the clay fraction. The presence of mobile forms of the elements in soils with high content of clay minerals is lower than in other types of soils (Palm 1994). Finally, the organic matter plays an important role in the heavy metal retention processes because of its high cation exchange capacity (Kalbitz and Wennrich 1998).

The soil beds developed onto the Manzanares riverbanks are of alluvial origin, relatively young, and with a poor pedological evolution. They show a differentia- tion in depth mainly due to the deposit of sediment (de Miguel et al. 2002). The samples collected have a $\mathrm{pH}$ value $\operatorname{circa} 7$, a loamy-sand class textural (13\% of clay, predominantly illite), and a percentage of organic matter that is characteristic of farmlands (1-4\%). These properties show suitable conditions for the retention of cationic metals: i) for this $\mathrm{pH}$, most of the soil constituents with variable electric charge are negatively charged, so having a high affinity for cations; and, furthermore, hydrolyzed metal species dominate instead of free hydrated forms involving those heavy metals and could be strongly adsorbed onto the solid surfaces. ii) Illite is not the clay with greater cation exchange capacity $(\mathrm{CEC}=10-40$ $\mathrm{cmol}_{\mathrm{c}} / \mathrm{kg}$ ), but it is very important in the retention of pollutants by independent $\mathrm{pH}$ charges. iii) Organic matter is the component of the soil solid fraction with larger reactivity $\left(\mathrm{CEC}=200 \mathrm{cmol}_{\mathrm{c}} \mathrm{c} / \mathrm{kg}\right)$, and, so, this organic matter percentage in the superficial horizons contributes to heavy metals retention. When the pollutants are retained by the constituents of the soil, heavy metals do not cross to deep horizons and reach groundwater. However, it is necessary to know the bioavailability of metal species to determine their toxicity since it warrants a concern, not only for the quality of soil, but also (and potentially) for groundwater and surface water systems.

The distribution of pollutants in these soil samples has probably been influenced by several factors, among others: (i) weathered products of the slag (due to climatic conditions); (ii) the use of agrochemicals to fight against pest (anthropogenic input of $\mathrm{Cd}, \mathrm{Pb}, \mathrm{Ni}$ and $\mathrm{Cr}$ ) and (iii) coal combustion. This preliminary study is only to determine the contaminant level of soils in the studied area. 
Nevertheless, further work is necessary to determine how such pollutants are transferred to the crops (through the calculation of the transfer factor), the evolution of soil fertility, the content of organic matter and the distribution of heavy metals in the ploughing layer of soil to assess the environmental risk linked to contaminated soils.

\section{CONCLUSIONS}

This study, in which several pathways and farmlands soil samples from the southern part of Madrid (Spain) have been investigated, demonstrates the presence of a high concentration of metal contaminants coming from heaps of steel slag. Chemical analyses of the slags samples, which were produced in the manufacturing process by the Aristriain factory during more than 40 years, revealed the presence of heavy metals introduced by iron scraps: $\mathrm{Fe}(43 \%), \mathrm{Mg}(26 \%), \mathrm{Cr}$ (1.1\%), Mn (till 4.6\%), in the form of Fe-rich slag phases (wüstite, magnetite, goethite...), and $\mathrm{Cr}$ (chromite), $\mathrm{Mn}$ (bustamite), together with a $6.5 \%$ of S, Si and Ca-rich phases (larnite, ghelenite, pseudowollastonite), and graphite. The XRF analyses performed on the farmlands soil samples demonstrate the presence of some of the heavy metals close to the threshold admitted by the local authorities for this use: $\mathrm{Co}$ (close to the limit, $15 \mathrm{ppm}$ ), $\mathrm{Pb}$ (over the limit in one of the analysed samples, $75 \mathrm{ppm}$ ) and $\mathrm{V}$ (some units over the allowed limit of $37 \mathrm{ppm}$ ). The pathways soil samples confirm important levels of $\mathrm{Fe}_{2} \mathrm{O}_{3}$ (about 20\%), $\mathrm{MgO}(5 \%), \mathrm{MnO}(0.8-2 \%)$ and traces of some other contaminants, such as $\mathrm{Cr}$ (up to $7726 \mathrm{ppm}$ ), $\mathrm{Zn}$ (up to 3531 ppm), $\mathrm{Ba}$ (up to $3143 \mathrm{ppm}$ ), $\mathrm{Pb}$ (up to $759 \mathrm{ppm}$ ) or $\mathrm{Cu}$ (up to $500 \mathrm{ppm}$ ). The $\mathrm{Cr}$ content exceeds the admitted limit for any possible use, whereas $\mathrm{Pb}$ and $\mathrm{Cu}, \mathrm{Co}, \mathrm{Zn}$, and $\mathrm{V}$ go beyond the limits for urban and other uses (e.g. agricultural use), respectively. These values are worrying since they involve a risk to human health. Further studies have to be performed to determine the mobility of the heavy metal elements and establish their toxicity not only for the quality of soil, but also for ground water and surface water systems. This sort of studies can provide useful information for the politicians regarding the appropriate use of the territory to prevent possible health hazard for the population.

At present, it is not possible to estimate the number of ton slag heaps in the whole area; so, no plans for remediation involving partial soil replacement in the whole affected area can be applied. Therefore, the study indicates that the multi-metal pollution in this area is of anthropogenic origin and the main source of metals is the slag. One of the solutions for this environmental pollution could be to employ these waste by-products in other fields, such as cement or ceramic industry, as raw material that could improve the quality of the final product.

\section{ACKNOWLEDGMENTS}

The present work was partially supported by CICYT FIS2007-61823, MATERNAS-S-0505/MAT/000094 projects and the JAE-DOC-047 CSIC contract (ECF). We are grateful to Dr. Martínez-Frías by supplying the original irradiated car-slag fragment and to Martin FernandezHernan by the slag heap exploration.

\section{RESUMO}

A presença de altos níveis de metais pesados envolve riscos à saúde humana e pode induzir doenças crônicas. Este trabalho relata a contaminação metálica causada por pilhas de escória siderúrgica acumulada durante mais de 40 anos em áreas industriais na parte sul de Madrid (Espanha). Amostras de escória e solo foram coletadas em uma área de $10 \mathrm{~km}^{2}$ e caracterizada por diferentes métodos, convencionais (XRD, XRF) ou não (ESEM, termoluminescência e EDS-WDS). A análise revela a presença de: i) quantidades importantes de $\mathrm{Fe}(43 \%)$, Mg (26\%), Cr (1,1\%), Mn (4,6\%), S (6,5\%) formando várias fases ricas em $\mathrm{Fe}$ (wüstita, magnetita), $\mathrm{Si}$ e $\mathrm{Ca}$ (larnita, guelenita), Cr (cromita), Mn (bustamita) e grafite; (ii) traços de outros contaminantes, como $\mathrm{Cr}$ (7700 ppm), Zn (3500 ppm), $\mathrm{Ba}$ (3000 ppm), Pb (700 ppm) e Cu (500 ppm), no solo dos caminhos para as pilhas de resíduos e (iii) Co (13 ppm), $\mathrm{Pb}$ (78 ppm) e V (54 ppm) em amostras de solo agrícola. Embora os teores de metais pesados não sejam apropriados para uso corrente, a elevada contaminação de áreas adjacentes é mais preocupante. Os solos adjacentes (pH ca. 7, 13\% de argila - principalmente ilita) e 1-4\% de matéria orgânica mostram condições adequadas para a retenção de cátions, mas outros estudos deverão ser realizados para determinar a possibilidade de riscos à saúde humana. Este tipo de trabalho pode fornecer informação útil para gestores públicos, com relação ao uso do território e prevenção de riscos à saúde da população.

Palavras-chave: EDS, ESEM, contaminação por metais, escória de aço, TL, XRD, XRF. 


\section{REFERENCES}

Agency for Toxic Substances and Disease RegISTRY (ATSDR). 1992. Toxicological Profile for vanadium. Atlanta, GA: U.S. Department of Health and Human Services, Public Health Service.

Agency for Toxic Substances and Disease RegISTRY (ATSDR). 2004. Toxicological Profile for cobalt. Atlanta, GA: U.S. Department of Health and Human Services, Public Health Service.

Agency for Toxic Substances And Disease RegISTRY (ATSDR). 2007. Toxicological Profile for Lead (Update). Atlanta, GA: U.S. Department of Health and Human Services, Public Health Service.

BøtTer-Jensen L AND Duller GAT. 1992. A new system for measuring optically stimulated luminescence from quartz samples. Nucl Tracks Rad Meas 20 (Part D): 549-553.

BRADL HB. 2004. Adsorption of heavy metal ions on soils and soils constituents. J Colloid Interf Sci 277: 1-18.

Chatterjee J and Chatterjee C. 2000. Phytotoxicity of cobalt, chromium and copper in cauliflower. Environ Pollut 109: 69-74.

COMUnidAD DE MADRID. 2006. Orden 2770/2006 de la Consejería de Medio Ambiente y Ordenación del Territorio de la Comunidad de Madrid.

Correcher V And Delgado A. 1998. On the use of natural quartz as transfer dosemeter in retrospective dosimetry. Radiat Meas 29: 411-414.

Correcher V, SANChez-Munoz L, Garcia-Guinea J AND DELGADo A. 2007. Natural blue thermoluminescence emission of the recently fallen meteorite in Villalbeto de la Pena (Spain). Nucl Instrum Meth A 580: 637640 .

Covelo EF, Vega FA And Andrade ML. 2007. Simultaneous sorption and desorption of $\mathrm{Cd}, \mathrm{Cr}, \mathrm{Cu}, \mathrm{Ni}, \mathrm{Pb}$, and $\mathrm{Zn}$ in acid soils I. selectivity sequences. J Hard Mater 147: 852-861.

De Miguel E et Al. 2002. Determinación de niveles de fondo y niveles de referencia de metales pesados y otros elementos traza en los suelos de la Comunidad Autónoma de Madrid. IGME, Madrid.

ENVironment Agency. 2002. Assessment of risks to human health from land contamination: an overview of the development of soil guideline values and related research. Bristol, UK, DEFRA.

GARCIA-GuineA J AND CORRECHER V. 2000. Luminescence spectra of alkali feldspars: Influence of crushing on the ultraviolet emission band. Spectrosc Lett 33: 103113 .
Gielen D AND Moriguchi Y. 2002. $\mathrm{CO}_{2}$ in the iron and steel industry: an analysis of Japanese emission reduction potentials. Energ Policy 30: 849-863.

Grytsyuk N, Arapis G, Perepelyatnikova L, IVANOVA T AND VYNOGRADS'KA V. 2006. Heavy metals effects on forage elements accumulation in crops yields and estimation of plants as affected by soil. Sci Total Environ 354 (2-3): 224-231.

Gunst S, Wenbruch S, Wentzel M, Ortner HM, Skogstad A, Hetland S And Thomassen Y. 2000. Chemical composition of individual aerosol particles in workplace air during production of manganese alloys. J Environ Monitor 2: 65-71.

KALBITZ K AND WeNNRICH R. 1998. Mobilization of heavy metals and arsenic in polluted wetland soils and its dependence on dissolved organic matter. Sci Total Environ 209: 27-39.

Luxan MP, Sotolongo R, Borrego F And Herrero E. 2000. Characteristics of the slags produced in the fusion of scrap steel by electric arc and furnace. Cement Concrete Res 30: 517-519.

Martin-Ramos JD. 2004. XPowder Software (Ver 2004. 01.05). A software package for cualitative and quantitative powder X-Ray diffraction analysis. http://www.ugr.es/ jdmartin.

MARTÍNEZ-FRÍAS J. 1998. La roca de Getafe: trayectoria de caída, efectos del impacto y marcadores morfotexturales de vuelo. Geogaceta 25: 215-218.

Martínez-Frías J, Weigel A, Marti K, Boyd T, WiLSON GH AND JULL T. 1999. The Getafe rock: Fall, composition and cosmic ray records of an unusual ultrarefractory scoriaceous material. Rev Metal 35: 308-315.

Martínez-Frías J, Benito R, Wilson G, Delgado A, BOYD T AND MARTI K. 2004. Analysis and chemical composition of larnite-rich ultrarefractory materials. J Mater Process Tech 147: 204-210.

MCKEEVER SWS. 1985. Thermoluminescence of solids. Cambridge Univ Press (Ed), Cambridge, p. 65-72.

Mochizuki M, Ueda F, SASAKi S ANd Hondo R. 1999. Vanadium contamination and the relation between vanadium and other elements in wild birds. Environ Pollut 106(2): 249-251.

PALM V. 1994. A model for sorption, flux and plant uptake of cadmium in a soil-profile - model structure and sensitivity analysis. Water Air Soil Poll 77 (1-2): 169-190.

PARAIS J. 1978. Fabricación de hierro, aceros y fundiciones. Vol 1-2, Urmo, S.A. (Eds), Bilbao (España), p. 529-530.

REN HM, WANG J AND ZHANG XL. 2006. Assessment of soil lead exposure in children in Shenyang, China. Environ Pollut 144: 327-335. 